\title{
STUDI HISTOPATOLOGI ORGAN HATI DAN GINJAL DARI TIKUS PUTIH (Rattus novergicus) SETELAH PEMBERIAN DOSIS TUNGGAL DAN BERULANG EKSTRAK ETANOL PARANG ROMANG (Boehmeria virgata (FORST) GUILL)
}

\author{
A. Endang Kusuma Intan ${ }^{1}$, Marianti A. Manggau ${ }^{1}$, Husni Cangara ${ }^{2}$ \\ ${ }^{1}$ Fakultas Farmasi, Universitas Hasanuddin, Makassar \\ ${ }^{2}$ Departemen Patologi dan Anatomi, Fakultas Kedokteran, Universitas Hasanuddin, Makassar
}

Kata Kunci

Boehmeria virgata, Hati, Histopatologi, Ginjal

\begin{abstract}
ABSTRAK
Penelitian invitro tentang aktivitas antiproliferatif daun Parang Romang (Boehmeria Virgata (Forst) Guill) telah diteliti pada sel Hela, untuk itu perlu dilakukan uji toksisitas untuk menentukan dosis dan keamanan dari tanaman tersebut pada hewan uji. Salah satu paramater dari uji toksisitas adalah pengamatan terhadap gambaran histopatologi organ. Penelitian ini bertujuan untuk pengaruh setelah pemberian dosis tunggal dan berulang ekstrak etanol daun parang romang terhadap perubahan histopatologi pada organ hati dan ginjal dari tikus putih jantan dan betina (Rattus novergicus). Pada pemberian dosis tunggal tikus dibagi menjadi 3 kelompok yaitu kelompok kontrol, kelompok 2000 $\mathrm{mg} / \mathrm{kg} \mathrm{BB}$, dan kelompok $5000 \mathrm{mg} / \mathrm{kg}$ BB kemudian dilakukan pengamatan selama 14 hari dan dikorbankan pada hari ke 15. Sedangkan pada pemberian dosis berulang selama 28 hari terdapat 4 kelompok, yaitu kelompok kontrol, kelompok $250 \mathrm{mg} / \mathrm{kg} \mathrm{BB}$, kelompok $500 \mathrm{mg} / \mathrm{kg} \mathrm{BB}$, dan kelompok $1000 \mathrm{mg} / \mathrm{kg}$ BB dan dikorbankan pada hari ke 29. Semua kelompok kontrol hanya diberikan akuades. Hasil dari penelitian menunjukkan terdapat pengaruh setelah pemberian dosis tunggal dan berulang ekstrak etanol daun parang romang (Boehmeria virgata Linn (Forst) Guill) terhadap gambaran histopatologi organ hati dan ginjal berupa degenerasi hidrofik dan pembesaran glomerulus dengan derajat kerusakan ringan sampai sedang, baik pada tikus putih jantan maupun betina (Rattus novergicus)
\end{abstract}

\section{Masuk 31-07-2018 \\ Revisi 25-08-2018 \\ Diterima 30-08-2018}

\section{Korespondensi}

\section{Marianti A Manggau} winati04@yahoo.co.id

\section{Copyright}

C 2018 Majalah Farmasi Farmakologi Fakultas Farmasi · Makassar

Diterbitkan tanggal 31-08-2018

Dapat Diakses Daring Pada:

\section{PENDAHULUAN}

Indonesia sebagai negara terkaya di dunia dalam kekayaan hayati, dengan luas yang 'hanya' 1,3\% dari luas total daratan dunia, Indonesia dianugerahi dengan kekayaan alam yang beraneka ragam. Salah satu bentuknya adalah tumbuhantumbuhan yang dapat dimanfaatkan sebagai obatobatan. Masyarakat secara turun temurun menggunakannya berupa ramuan untuk pengobatan.

Meskipun obat tradisional sudah dimanfaatkan sejak lama namun tidak sepenuhnya aman, karena obat tradisional merupakan senyawa asing bagi tubuh, sehingga sangatlah penting mengetahui potensi ketoksikannya. Untuk mengetahui itu maka perlu dilakukan suatu uji untuk mendeteksi efek toksik suatu zat pada sistem biologi dan untuk memperoleh data dosis respon yang khas dari sediaan uji. Data yang diperoleh dapat digunakan untuk memberi informasi mengenai derajat bahaya sediaan uji tersebut bila terjadi pemaparan pada manusia, sehingga dapat ditentukan dosis penggunaannya demi keamanan manusia (1).

Salah satu tumbuhan endemik yang dimanfaatkan masyarakat sebagai bahan obat tradisional adalah Parang romang (Boehmeria virgata (Forst) Guill). Marianti Manggau, et al (2), menyatakan bahwa masyarakat Tana Toraja (Sulawesi Selatan) menggunakan tanaman ini terutama bagian daunnya sebagai obat kanker. Tumbuhan ini tumbuh di daerah-daerah pegunungan seperti Sinjai, Malino, Maros dan Enrekang (3).
Selain itu berdasarkan penelitian sebelumnya telah diketahui bahwa ekstrak etanol memiliki aktivitas sitotoksik kuat terhadap sel line kanker servix HeLa secara in vitro dan tidak memiliki aktivitas sitotoksik terhadap sel normal sel vero (4). Kemudian telah diperoleh senyawa aktif anti kanker dari ekstrak heksan yaitu senyawa alkaloid BV03 yang berefek anti proliferasi terhadap sel line HeLa secara in vitro. Mekanisme kerja isolat BV03 juga telah diteliti yaitu melalui peningkatan ekspresi gen Caspase-3 dan p53 (5).

Mengingat penggunaannya sebagai tanaman obat, maka tanaman ini harus melalui serangkaian uji. Salah satunya adalah uji keamanan melalui uji toksisitas akut dan subkronis oral sebelum dikembangkan menjadi herbal terstandar. Pada pengujian toksisitas baik akut maupun subkronis memiliki beberapa parameter uji. Salah satunya adalah gambaran histopatologi dari organ vital hewan uji. Untuk dapat memberikan penjelasan ilmiah tentang patologi yang terjadi setelah pemaparan zat uji dengan dosis tunggal maupun secara berulang selama jangka waktu tertentu. Untuk itu, penelitian ini bertujuan untuk mengetahui pengaruh pemberian ekstrak etanol daun parang romang (Boehmeria virgata (Forst) Guill) yang diberikan dengan dosis tunggal maupun efek kumulatifnya setelah pemberian berulang dalam jangka waktu tertentu terhadap gambaran histopatologi serta berat relatif organ hati dan ginjal dari tikus betina dan jantan galur wistar (Rattus novergicus). 


\section{METODE PENELITIAN}

\section{Alat dan Bahan}

Alat-alat yang digunakan adalah alat bedah steril, embedding cassete, cover glass, gunting, gelas beker (pyrex), gelas ukur (pyrex), pipet tetes, spatula, batang pengaduk, erlenmeyer (pyrex), labu $100 \mathrm{ml}$ (pyrex), kaca preparat, kandang tikus, masker, mikroskop, mikrotom, papan bedah, timbangan analitik, timbangan hewan, rotary evaporator, wadah maserasi dan oven.

Bahan-bahan yang digunakan adalah alkohol, aquadestillata, ekstrak etanol (Boehmeria virgata Linn (Forst) Guill), etanol, eter, larutan formalin $10 \%$, parafin, pakan, pewarna haematoksilin-eosin dan tikus betina dan jantan galur wistar.

\section{Prosedur Penelitian}

\section{Penyiapan sampel penelitian}

Sampel daun Parang romang (Boehmeria virgata Linn (Forst) Guill) diperoleh di daerah Malino (Kabupaten Gowa, Sulawesi Selatan). Sampel daun parang romang kemudian dicuci dengan air mengalir, kemudian disortasi basah, dipotong kecil-kecil, dan dicuci bersih dengan air mengalir lalu dikeringkan dalam Lemari pengering simplisia hingga kering, selanjutnya dilakukan ekstraksi. Sebanyak $1 \mathrm{~kg}$ serbuk daun tumbuhan parang romang (B. virgata) dimaserasi dengan etanol sebanyak 10 L selama $1 \times 24$ jam, kemudian campuran sampel dan pelarut ini disaring hingga diperoleh ekstrak dan ampas, ampas yang dihasilkan kemudian kembali dimaserasi dengan pelarut yang sama. Langkah tersebut diulangi sampai 4 kali total maserasi, selanjutnya seluruh ekstrak yang diperoleh disatukan dan dipekatkan dengan Rotary Vacum Evaporator sampai diperoleh ekstrak etanol pekat.

\section{Penyiapan Hewan Uji}

\section{Uji Toksisitas Akut}

Penelitian dilakukan pada 9 ekor tikus putih betina (rattus novergicus) galur wistar, yang terdiri atas 3 kelompok, yaitu kelompok kontrol, kelompok $2000 \mathrm{mg} / \mathrm{Kg} \mathrm{BB}$, dan kelompok $5000 \mathrm{mg} / \mathrm{Kg}$ BB. Tikus dipelihara dalam ruangan dengan siklus gelap dan terang sekitar 12 jam, kelembapan $70 \%$, suhu sekitar $26^{\circ} \mathrm{C}$ dengan ventilasi cukup. Tikus dimasukkan dalam kandang sebanyak 3 ekor per kandang dengan jenis kelamin sama. Makanan dan minuman diberikan ad libitum.

\section{Uji Toksisitas Subkronik}

Penelitian dilakukan pada 40 ekor tikus putih jantan dan betina (rattus novergicus) galur wistar, yang terdiri atas 4 kelompok, yaitu kelompok kontrol, kelompok $250 \mathrm{mg} / \mathrm{Kg} \mathrm{BB}$, kelompok $500 \mathrm{mg} / \mathrm{Kg}$ BB dan kelompok $1000 \mathrm{mg} / \mathrm{Kg} \mathrm{BB}$. Tikus dipelihara dalam ruangan dengan siklus gelap dan terang sekitar 12 jam, kelembapan $70 \%$, suhu sekitar $26^{\circ} \mathrm{C}$ dengan ventilasi cukup. Tikus dimasukkan dalam kandang sebanyak 5 ekor per kandang dengan jenis kelamin sama. Makanan dan minuman diberikan ad libitum.

\section{Prosedur Perlakuan}

\section{Uji Toksisitas Akut}

Metode uji toksisitas akut yang dilakukan mengikuti prosedur OECD/OCDE 425 UP and DOWN tahun 2008. Hewan dikelompokkan berdasarkan estimasi dosis $\mathrm{LD}_{50}$ dari software AOT 425 yaitu kelompok dosis $2000 \mathrm{mg} / \mathrm{KgBB}$ dan $5000 \mathrm{mg} / \mathrm{KgBB}$. Kemudian ditambah dengan kelompok kontrol. Hewan harus berpuasa sebelum pemberian dosis (makanan tapi kecuali air harus ditahan dalam semalam). Pemberian dosisnya dihitung sesuai berat badan. Setelah ekstrak etanol daun parang romang diberikan, makanan dapat ditahan 3-4 jam sebelum kembali diberikan pada tikus. Setelah itu hewan uji diamati setiap 30 menit selama 4 jam dan selanjutnya diamati setiap hari sampai 14 hari. Tandatanda toksisitas yang diamati meliputi, kulit dan bulu, mata, letargi (kelesuan), konvulsi (kejang), tremor (gemetar), diare, dan mati. Dilakukan evaluasi berat badan setiap 1 minggu sekali (6).

\section{Uji Toksisitas Subkronik}

Uji toksisitas subkronis menggunakan metode uji toksisitas subkronis singkat oral selama 28 hari menurut BPOM tahun 2014. Hewan harus berpuasa sebelum pemberian ekstrak etanol daun parang romang (makanan tapi kecuali air harus ditahan dalam semalam). Hewan uji dibagi dalam 4 kelompok, masing-masing kelompok terdiri dari 10 ekor tikus ( 5 tikus jantan dan 5 tikus betina). Kelompok 1 adalah kelompok kontrol (aquadest), kelompok 2 adalah kelompok konsentrasi rendah $(250 \mathrm{mg} / \mathrm{Kg}$ BB ekstrak etanol daun parang romang), kelompok 3 adalah kelompok konsentrasi sedang (500 mg/Kg BB ekstrak etanol daun parang romang), dan kelompok 4 adalah kelompok konsentrasi tinggi (1000 $\mathrm{mg} / \mathrm{Kg}$ BB ekstrak etanol daun parang romang). Dilakukan juga evaluasi berat badan tiap minggu serta pengamatan terhadap intake makanan dan minuman dari hewan uji untuk mengetahui pengaruhnya terhadap berat badan hewan uji. Setelah pengujian berakhir, dilakukan pengamatan selama 14 hari terhadap hewan uji (kelompok satelit) yang bertahan untuk mengetahui pengaruh lebih lanjut (1).

\section{Pemeriksaan Histopatologi Organ Hati dan Ginjal}

Pemeriksaan histopatologi ini dilakukan untuk melihat pengaruh dari pemberian estrak etanol parang romang terhadap organ hati dan ginjal hewan uji. Hewan uji yang masih bertahan hidup sampai hari ke 14 setelah pemberian ekstrak dosis tunggal (uji toksisitas akut) dan 28 hari setelah pemberian dosis berulang (uji toksisitas subkronik), dikorbankan. Kemudian dilakukan pembedahan untuk mengambil organ hewan uji pada hari ke 15 dan 29. Kemudian organ diamati secara makroskopik, dihitung berat relatif organ, setelah itu organ yang diambil difiksasi dengan larutan formalin $10 \%$ dan pengecatan dengan Hematoksilin Eosin (HE). Preparat diamati dibawah mikroskop cahaya untuk melihat organ secara mikroskopis sesuai dengan perbesaran yang diinginkan. Pengamatan mikroskopik dilakukan secara dengan menghitung jumlah persentase sel hati dan ginjal yang mengalami degenerasi hidropik dan pembesaran glomerulus ginjal untuk mengetahui derajat kerusakannya. Derajat kerusakan ditentukan secara deskriptif berdasarkan metode mitchel (7).

\section{Pengolahan dan Analisis Data}

Data diperoleh dari hasil persentase degenerasi hidrofik dan pembesaran glomerulus dan disajikan dalam bentuk ratarata \pm SEM. Pertama-tama dilakukan uji normalitas dengan uji Shapiro Wilk. Apabila didapatkan distribusi data yang normal, maka dilakukan uji beda menggunakan uji One Way Anova dan jika didapatkan nilai $\mathrm{p}<0,05$, dilanjutkan dengan analisis Post Hoc. Apabila didapatkan distribusi data yang tidak normal, maka dilakukan uji beda menggunakan uji Kruskal-Wallis dan jika didapatkan nilai $\mathrm{p}<0,05$, maka dilanjutkan dengan uji Mann-Whitney. Semua analisis statistik dilakukan menggunakan program SPSS 16 pada tingkat kepercayaan 95\% $(p=0,05)(8)$.

\section{HASIL DAN PEMBAHASAN}

Pada penelitian ini, simplisia yang digunakan adalah daun parang romang (Boehmeria virgata Linn (Forst) Guill) dan diperoleh di daerah Malino (Kabupaten Gowa, Sulawesi Selatan). Daun yang digunakan adalah daun yang berwarna hijau dan masih segar.

Daun kemudian disortasi basah, dipotong kecil-kecil, dan dicuci bersih dengan air mengalir lalu dikeringkan dalam Lemari pengering simplisia hingga kering, selanjutnya 
dilakukan ekstraksi. Sebanyak $10 \mathrm{~kg}$ serbuk daun tumbuhan parang romang (B. virgata) dimaserasi dengan etanol sebanyak 60 L selama 1 x 24 jam, kemudian campuran sampel dan pelarut ini disaring hingga diperoleh ekstrak dan ampas, ampas yang dihasilkan kemudian kembali dimaserasi dengan pelarut yang sama. Langkah tersebut diulangi sampai 4 kali total maserasi, selanjutnya seluruh ekstrak yang diperoleh disatukan dan dipekatkan dengan Rotary Vacum Evaporator sampai diperoleh ekstrak etanol pekat.

Kemudian dilakukan uji toksisitas akut (dosis tunggal) dan subkronik (berulang) pada hewan uji setelah itu hewan uji yang bertahan hingga 14 hari pada uji toksiitas akut dan 28 hari untuk toksisitas subkronik dilakukan pembedahan masing-masing satu hari setelah akhir masa uji. Yaitu pada hari ke 15 dan 29. Dilakukan pengamatan secara makroskopik dan dihitung berat relatif organ hati da ginjal, Setelah itu difiksasi dengan larutan formalin $10 \%$ dan pengecatan dengan pewarna HE. Kemudian diamati secara mikroskopik untuk melihat kerusakan yang terjadi pada sel hati dan ginjal.

Pada pengamatan secara mikroskopik setelah pemberian dosis tunggal terlihat terjadi degenerasi hidrofik pada sel hati dan ginjal serta pembesaran glomerulus. Penentuan derajat kerusakan dilakukan dengan metode mitchel yaitu dengan menghitung persen degenerasi hidrofik dan pembesaran glomerulus yang terjadi. Kemudian digolongkan derajat kerusakan yang terjadi berdasarkan persentase tersebut. Hasil dari pengamatan pada semua kelompok menunjukkan bahwa persen degenerasi hidrofik dan pembesaran glomerulus meningkat seiring dengan meningkatnya dosis pemberian ekstrak.

Sel-sel pada organ hati sangat rawan sebagai tempat metabolisme begitu pula pada organ ginjal sel-selnya terutama pada sel-sel epitel tubulus yang berfungsi sebagai tempat reabsorbsi memungkinkan kedua organ ini kontak langsung dengan toksisikan yang menyebabkan resiko terpapar senyawa toksik lebih besar. Hal tersebut dapat menyebabkan terjadinya perubahan fungsi pada selnya. Proses kerusakannya dimulai dari terjadinya degenerasi. Degenerasi hidrofik adalah kerusakan yang ringan dan bersifat reversibel atau dapat kembali menjadi normal jika penyebabnya dihilangkan (9). Degenerasi hidrofik sebagai respon terhadap infeksi atau paparan dari toksikan. Toksikan tersebut menyebabkan gangguan pada organel mitokondria yang menghasilkan ATP sebagai bahan bakar untuk bekerjanya pompa natrium $(\mathrm{Na}+)$. Apabila tidak ada ATP maka natrium $(\mathrm{Na}+)$ yang ada dalam sel tidak akan keluar dari sel. Dimana natrium $(\mathrm{Na}+)$ memiliki sifat menarik air. Hasilnya terlihat vakuola yang berisi air, jernih, kecil dan banyak didalam sitoplasma. Vakuola-vakuola tersebut bersatu membentuk vakuola yang lebih besar atau vakuola tunggal yang menempati di dalam sitoplasma dan menggantikan inti sel serta terjadi pembengkakan seL (10).

Persen degenerasi hidrofik pada sel hati setelah pemberian dosis tunggal pada tikus betina menunjukkan hasil yang signifikan setelah uji ANOVA dan dilanjutkan dengan uji LSD untuk melihat perbedaan antar kelompok. Diperoleh hasil bahwa kelompok kontrol berbeda nyata $(\mathrm{p}<0,05)$ dibandingkan dengan kelompok $5000 \mathrm{mg} / \mathrm{Kg}$ tetapi tidak berbeda nyata dengan kelompok perlakuan $2000 \mathrm{mg} / \mathrm{Kg} \mathrm{BB}$ Persentase degenerasi pada sel ginjal tikus betina menunjukkan nilai signifikansi $(0,051)$ pada uji nonparametrik kruskal wallis yang artinya tidak ada pengaruh pemberian dosis tunggal ekstrak etanol daun parang romang $(\mathrm{P}<0,05)$ terhadap persentase degenerasi hidrofik organ ginjal tikus betina. Sedangkan pada persentase pembesaran glomerulus hasil dari uji kruskal wallis yaitu 0,610 $(<0,05)$ menunjukkan bahwa tidak ada perbedaan pada persentase pembesaran glomerulus ginjal tikus putih betina setelah pemberian dosis tunggal ekstrak etanol daun parang romang (Boehmeria virgata (Forst)).

Pada persentase degenerasi hidrofik yang $<25 \%$ di kategori normal (gambar 1) terlihat sel yang tampak lebih pucat dibandingkan sel normal dan terdapat vakoula mengandung air pada sitoplasma, namun persentase kerusakannya belum mencapai $25 \%$ dalam satu lapang pandang sehingga masih dikategorikan normal. Sedangkan untuk kategori ringan (kerusakan mencapai $25 \%$ ) menunjukkan gambaran histologi yang sama terlihat lebih pucat, sitoplasma mengandung vakoula dan bahkan tak jarang mendesak inti sel ketepi (gambar 2). Histologi dengan kategori sedang (kerusakan mencapai 50\%) menunjukkan gambaran yang sama dengan penampakan degenerasi yang semakin jelas (gambar 3).
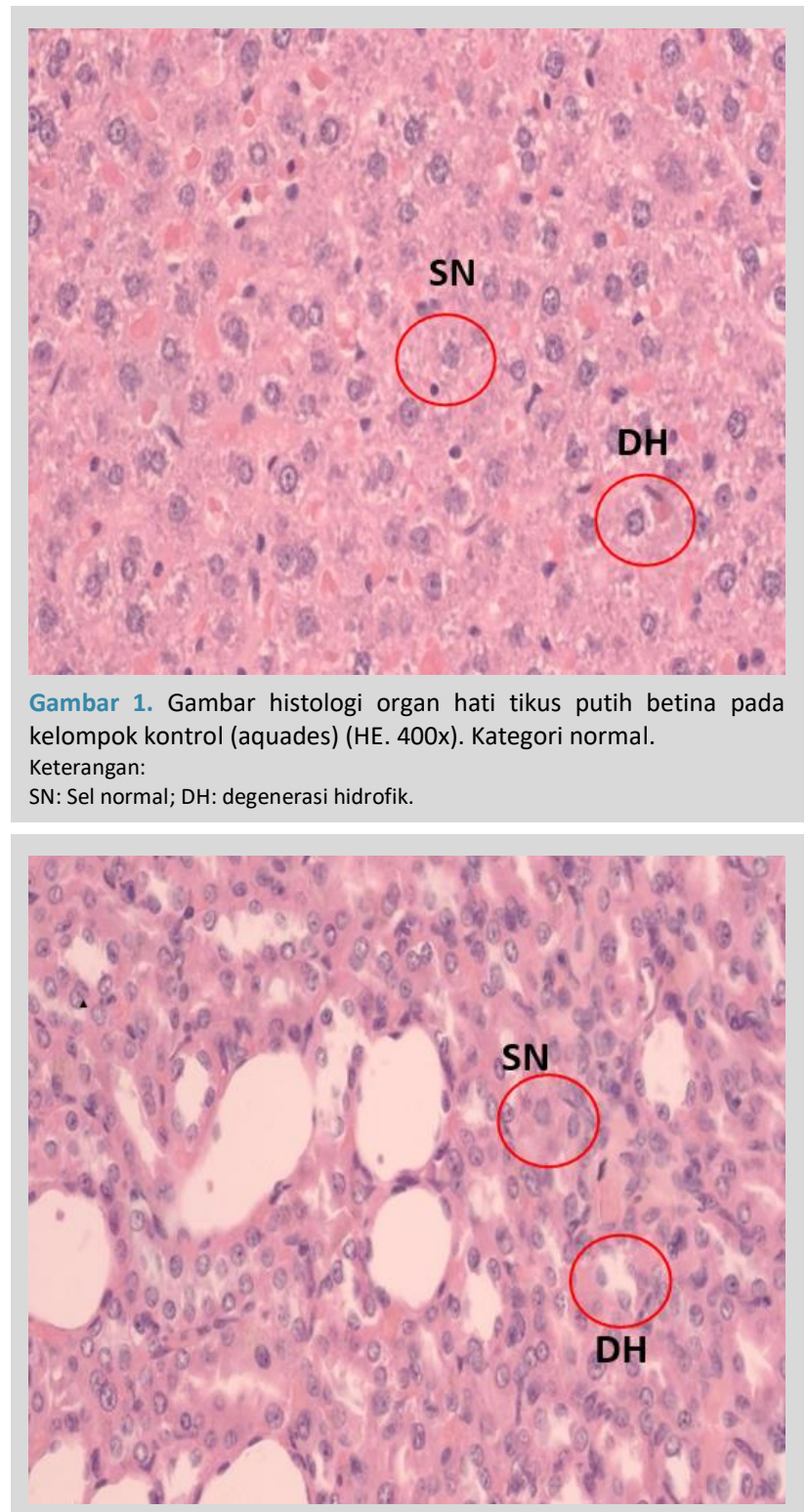

Gambar 2. Gambar histologi organ ginjal tikus putih betina setelah pemberian dosis tunggal (akut) ekstrak etanol parang romang (Boehmeria virgata Linn (Forst) Guill) pada kelompok $5000 \mathrm{mg} / \mathrm{Kg} \mathrm{BB}$ (HE. 400x). Kategori Ringan.

Keterangan:

SN: Sel normal; DH: degenerasi hidrofik.

Peningkatan diameter glomerulus atau pembesaran glomerulus terjadi akibat adanya interaksi antara senyawa toksik dan pembuluh darah yang dapat mengakibatkan adanya vasodilatasi pembuluh darah. Vasodilatasi ini menyebabkan membesarnya anyaman kapiler glomerulus, sehingga diameternya bertambah serta menyebabkan ruang kapsula bowman menjadi menyempit (10). Gambar 4 menun- 
jukkan histologi glomerulus normal yang sama sekali tidak memperlihatkan pembesaran glomerulus dalam satu lapang pandang. Dengan bentuk glomerulus yang terllihat normal pada pada semua sisi sehingga ruang kapsuler juga terlihat dengan jelas. Sedangkan pada gambaran histologi pembesaran glomerulus kategori ringan (kerusakan mencapai 25\%) memperlihatkan glomerulus yang membesar pada satu sisi sehingga menyebabkan ruang kapsuler pada sisi tersebut menyempit dan pada sisi lain terlihat lebih lebar (gambar 5).

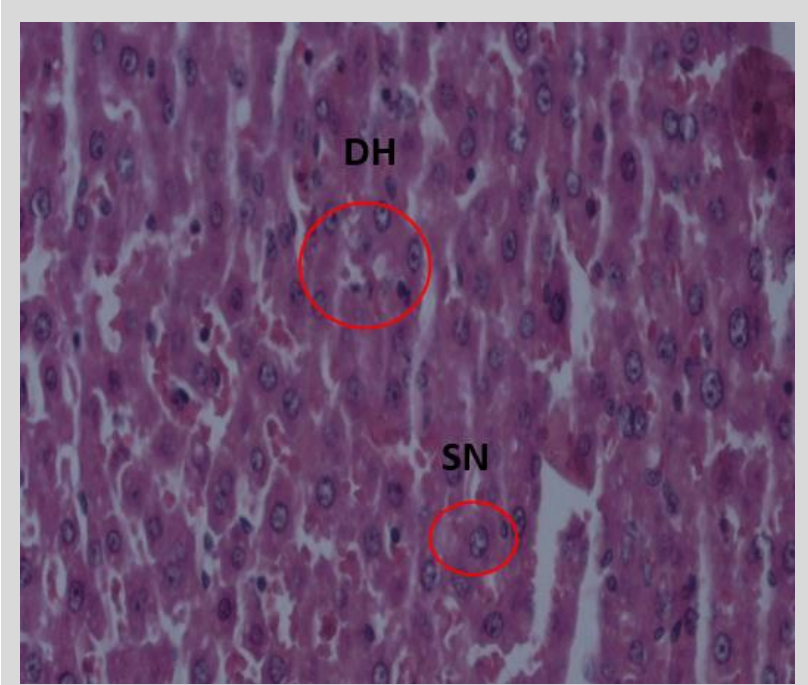

Gambar 3. Histologi organ hati tikus putih jantan setelah pemberian dosis berulang (akut) ekstrak etanol parang romang (Boehmeria virgata Linn (Forst) Guil pada kelompok 500 mg/Kg BB (HE. 400x). Kategori Sedang.

Keterangan:

SN: Sel normal; DH: degenerasi hidrofik.

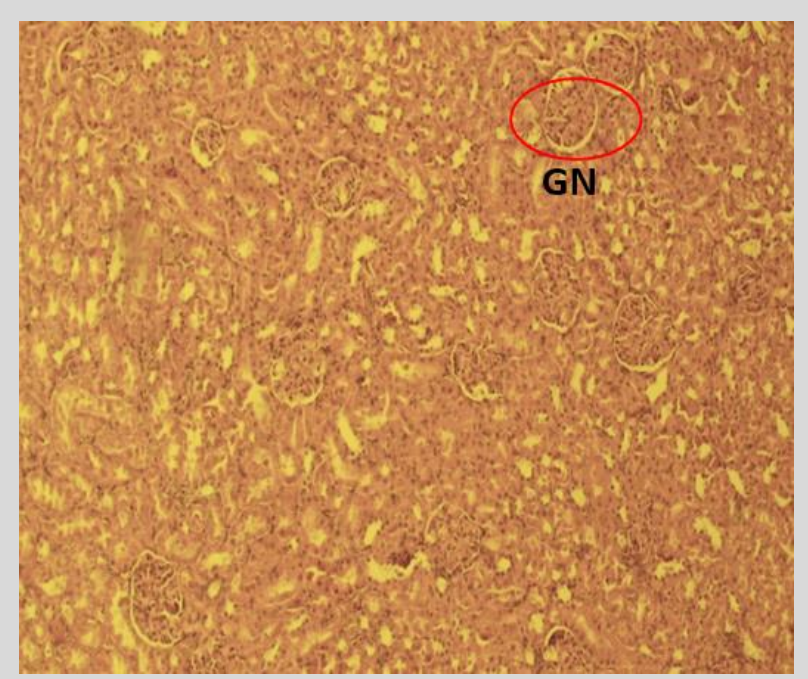

Gambar 4. Histologi Glomerulus ginjal tikus putih betina pada kelompok kontrol (aquades) (HE. 100x). Kategori Normal.

Keterangan:

GN: Glomerulus Normal.

Berdasarkan uji ANOVA data persentase degenerasi hidrofik pada sel hati setelah pemberian dosis berulang selama 28 hari pada tikus jantan dan betina menunjukkan nilai signifikansi $0,216(P>0,050)$ yang diuji untuk tikus jantan. Sedangkan 0,055 $(\mathrm{P}>0,050)$ untuk tikus betina, nilai tersebut menunjukkan bahwa tidak terdapat pengaruh yang berarti pada gambaran histopatologi organ hati tikus putih jantan maupun betina setelah pemberian dosis berulang ekstrak etanol parang romang selama 28 hari. Pada uji ANOVA degenerasi hidrofik organ ginjal tikus betina diperoleh nilai signifikansi 0,243 ( $\mathrm{P}>0,05)$ maka disimpulkan bahwa tidak terdapat pengaruh yang signifikan terhadap persentase degenerasi hidrofik pada organ ginjal tikus putih betina setelah pemberian dosis berulang ekstrak etanol parang romang. Sedangkan untuk tikus jantan diperoleh hasil yaitu $0,030 \quad(\mathrm{P}<0,05)$ yang artinya terdapat pengaruh yang signifikan. Dengan demikian terdapat pengaruh terhadap persentase degenerasi hidrofik dari organ ginjal tikus putih jantan setelah pemberian dosis berulang ekstrak etanol parang romang kemudian analisa dilanjutkan dengan uji posthoc (LSD). Hasilnya menunjukkan bahwa kelompok kontrol berbeda nyata dengan kelompok perlakuan 250 $\mathrm{mg} / \mathrm{Kg}$ BB dan $500 \mathrm{mg} / \mathrm{Kg} \mathrm{BB}$.

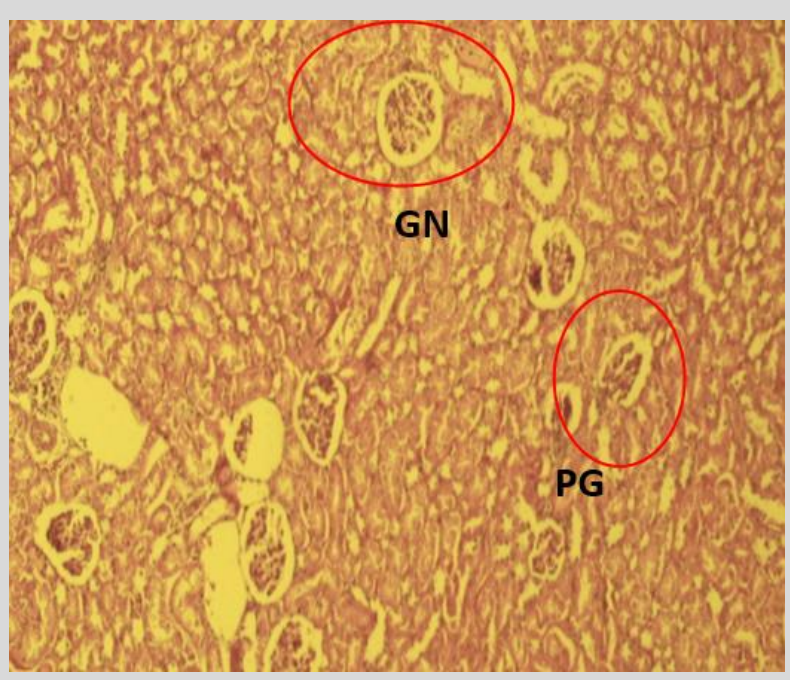

Gambar 3. Histologi glomerulus ginjal tikus putih betina setelah pemberian dosis tunggal (akut) ekstrak etanol parang romang (Boehmeria virgata Linn (Forst) Guill) pada kelompok 1000 mg/Kg BB (HE. 100x). Kategori sedang.

Keterangan:

GN: glomerulus normal; PG: pembesaran glomerulus.

Hasil uji ANOVA dari data persentase pembesaran glomerulus setelah pemberian dosis berulang menunjukkan hasil nilai signifikasi untuk tikus jantan nilai yang tidak signifikan $(p>0,05)$ sehingga dapat disimpulkan bahwa tidak terdapat pengaruh pemberian dosis berulang (subkronik) ekstrak etanol parang romang (Boehmeria virgata Linn (Forst) Guill terhadap pembesaran glomerulus ginjal tikus putih jantan. Tetapi sebaliknya untuk tikus putih betina diperoleh hasil nilai signifikansi 0,04 $(p<0,05)$. Hal tersebut menunjukkan bahwa terdapat pengaruh pemberian dosis berulang (subkronik) ekstrak etanol parang romang (Boehmeria virgata Linn (Forst) Guill terhadap pembesaran glomerulus ginjal tikus putih betina. Dan untuk mengetahui perbedaan pada tiap kelompok maka analisa dilanjutkan dengan uji posthoc (LSD). Hasil uji memperlihatkan bahwa hasil uji beda antar kelompok didapatkan persentase pembesaran glomerulus tikus putih betina antar kelompok kontrol dan seluruh kelompok perlakuan, yaitu antara kelompok $250 \mathrm{mg} / \mathrm{Kg} \mathrm{BB}$, kelompok $500 \mathrm{mg} / \mathrm{Kg} \mathrm{BB}$, dan kelompok $1000 \mathrm{mg} / \mathrm{Kg} \mathrm{BB}$ terdapat perbedaan yang bermakna dimana $(\mathrm{p}<0,05)$.

\section{KESIMPULAN}

Hasil dari penelitian menunjukkan terdapat pengaruh setelah pemberian dosis tunggal dan berulang ekstrak etanol daun parang romang (Boehmeria virgata Linn (Forst) Guill) terhadap gambaran histopatologi organ hati dan ginjal berupa degenerasi hidrofik dan pembesaran glomerulus dengan derajat kerusakan ringan sampai sedang, baik pada tikus putih jantan maupun betina (Rattus novergicus).

\section{UCAPAN TERIMA KASIH}

Penulis mengucapkan terima kasih kepada Allah Subhanahuwata'ala kemudian kedua orang tua. Penulis juga 
berterima kasih kepada pembimbing dan Penulis juga berterima kasih kepada Fakultas Farmasi Universitas Hasanuddin.

\section{DAFTAR PUSTAKA}

1. Badan Pengawas Obat dan Makanan Republik Indonesia (BPOM). 2014 Pedoman Uji Toksisitas Nonklinik secara In Vivo. Jakarta: Badan Pengawas Obat dan Makanan Republik Indonesia (BPOM).

2. Manggau, M.A., Hasan, H., Wahyudin, E., Haryono, K., Mufidah, dan Lukman. 2011. Efek Farmakologi Tanaman Antikanker yang Digunakan oleh Masyarakat Sulawesi Selatan. Balitbanda Sulawesi Selatan.

3. Rusdi, Ayu, K, Fauziah, dan Bariun, H. 2017. Uji Toksisitas Akut Ekstrak Partisi Akar Parang Romang (Boehmeria Virgata (Forst) Guill) terhadap Larva Artemia Salina Leach dengan Metode Brine Shrimps Lethality Test. JF FIK UINAM. Vol.5 No.3. 166-167.

4. Wardihan, Rusdi, Alam, G, Lukman dan Manggau, MA, 2014. Elective Cytotoxicity Evaluation in Anticancer Drug Screening of Boehmeria virgata (Forst) Guill Leaves to Several Human Cell Lines: Hela, WiDr, T47D and Vero. Dhaka Univ. J. Pharm. Sci.12(2). 87.

5. Manggau, M.A., Lukman, Muhammad Rusdi, Mochammad Hatta, Wardihan dan Subehan. 2014. Effect of an Isolated Active Compund (BV103) of Boehmeria virgata (Forst) Guill Leaves on Anti-poliferation in Human Cancer Cervix Hela Cells through Activation of Caspase 3 and p53 Protein. Jurnal Tropical medicine and Surgery.

6. Organization for Economic Cooperation and Development (OECD). 2008. OECD Guideone For Testing of Chemicals, Acute Oral Toxicity: Up-andDown Procedure No. 425. Paris: Organization for Economic Cooperation and Development.

7. Gufron M.2001. Gambaran Struktur Histologi Hepar dan Ren Mencit Setelah Pemberian Perlakuan Infus Akar Rimpang Jahe (Zingiber officinale) dengan Dosis Bertingkat. Jurnal Kedokteran Yarsi

8. Purnomo, H., dan Eka S., 2017. Statistika Farmasi. Yogyakarta: CV. Grafika Indah

9. Himawan. 1992. Kumpulan Kuliah Patologi. Jakarta: UI Press

10. Takude. R. L. 2014. Gambaran Histopatologi Hati Tikus Wistar Yang Diberikan Boraks.Jurnal E-Biomedik (Ebm).2:3 